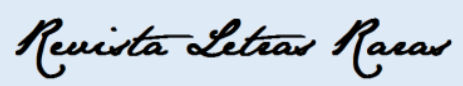

ISSN: $2317-2347$ - v. 6, n. 3 (2017)

\title{
A PRÁTICA EDUCATIVA NO FILME NENHUM A MENOS E SEU DIÁLOGO COM O PENSAMENTO FREIREANO
}

\author{
Carlos Roberto Gonçalves da Silva* \\ Maria Célia do Nascimento**
}

Resenha sobre o filme e o livro:

NENHUM A MENOS. Direção: Zhang Yimou. Roteiro: Xiangsheng Shi. China: Cine Pipoca Cult, 1999. Disponível em: http://www.cinepipocacult.com.br/2011/11/nenhum-menos.html. Acesso em: 10 de julho de 2017.

FREIRE, Paulo. Pedagogia da Autonomia: saberes necessários à prática educativa. $51^{\mathrm{a}}$ ed. Rio de Janeiro: Paz \& Terra, 2015.

Uma China de grandes contrastes e dualidades, em que a política da escolarização de crianças não é tão promissora em todas as áreas como destaca a propaganda internacional sobre o país. Eis o cerne do instigante "Nenhum a menos". Classificado como pertencente ao gênero dramático, o filme apresenta um caráter quase documental, ao retratar a educação nas entranhas, por vezes ocultadas, de um país que no ranking mundial aparece como rico. Podese crer que seja este o motivo de o longa-metragem ser comovente, além de prender os que o assistem ao produzir uma reflexão sobre a prática educativa, tendo como foco o professor.

A obra cinematográfica dirigida brilhantemente por Zhang Yimou representa a vida pacata na aldeia de Shuiquan, região marcada pela vida dura e pobreza dos seus aldeões. Nela há apenas uma escola primária já antiga e um único professor para atender crianças de idades e estágios de aprendizagem distintos, todas reunidas em uma mesma turma. O professor titular, Gao Enman, necessita se ausentar do cargo para cuidar de sua mãe que está muito doente, precisando, assim, encontrar a todo custo um substituto.

Após uma longa busca, o Chefe da Aldeia encontra uma única menina de 13 anos que se habilitou a ensinar durante o mês em que o titular da escola de Shuiquan estivesse fora. Contudo, ao ser apresentada ao professor Gao, Wei Minzhi recebe reações negativas por ser jovem demais (uma menor), não ter a formação mínima exigida para ser um professor e ter

\footnotetext{
* Graduando em Letras-Português na Universidade Federal de Campina Grande.

** Formada em Letras-Língua Portuguesa pela Universidade Estadual da Paraíba no ano de 2013. Atualmente é mestranda do Programa de Pós-Graduação em Linguagem e Ensino da Universidade Federal de Campina Grande, inserida na Linha de Pesquisa Língua(gem) em contexto de ensino de Português-Língua Materna.
} 


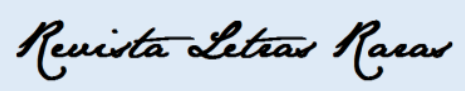

ISSN: $2317-2347$ - v. 6, n. 3 (2017)

uma personalidade bastante introvertida, além de não possuir conhecimentos vastos para serem "aplicados" nas atividades cotidianas da escola.

Embora exista a dificuldade de confiança na pequena garota, ela é aceita para o cargo, pois não há qualquer outro interessado nele. Assim, o titular Gao põe nas mãos da menina Wei duas tarefas maiores: ensinar canções aos alunos e copiar um capítulo da lição por dia. Destaca-se esse número porque apenas um giz deve ser gasto por dia, tendo em vista as condições financeiras do povoado e a impossibilidade de se comprar, periodicamente, uma nova caixa de giz, que é um elemento importantíssimo dentro daquele contexto, tendo em vista que os exercícios eram de cópia, em quadro negro e memorização.

Cabe ressaltar aqui que há uma ênfase, até certo momento do filme, na chamada "pedagogia tradicional”, caracterizada pela repetição nos exercícios, fortemente marcada pela atividade de memorização, sem reflexão crítica acerca dos conteúdos ensinados. Pode-se ir além nessa análise, à luz dos pensamentos de Freire (2015), pois não há dentro da visão do professor Gao sobre a prática educativa, estímulos para que os alunos transformem a sua curiosidade ingênua, associada ao saber do senso comum, em curiosidade epistemológica, sendo esta a curiosidade que se criticiza.

É de fundamental importância explicitar o motivo do título deste filme. Quando fora contratada, foi prometido a ela 50 Yuan como pagamento. Na madrugada em que o Prof. Gao iria embora, Wei pediu ao Chefe da Aldeia que lhe pagasse o combinado, e recebendo uma resposta negativa, foi acalmada pelo professor Gao, que lhe dissera para não perder nenhum aluno, e que, quando retornasse e nenhum dos 28 alunos tivesse desistido, ela receberia dele mais 10 Yuan. Isso gerou interesse na menina, por ser igualmente pobre. Todavia, esse interesse mudaria de foco em breve.

Nos primeiros dias de aula que sucedem a saída do professor titular, é mostrada uma postura extremamente infantil da garota que foi posta como professora. Tornam-se constantes suas saídas da sala de aula, deixando os alunos sozinhos e em um verdadeiro estado caótico, para talvez pensar sobre a atividade que desempenha de forma absolutamente improvisada. Quando uma aluna pede que ela intervenha nas travessuras de outro aluno, Wei apenas responde: "Não posso fazer nada". Fica claro para aqueles que assistem a cena o fato de ela não se enxergar como uma professora, mas como uma criança. E isso não se restringe a esse momento porque diversas outras cenas corroboram essa ideia. Assim, vem à baila o pensamento de Paulo Freire, ao dizer que o ensino exige do professor trabalhar a rigorosidade 


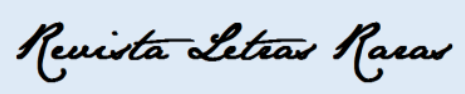

ISSN: $2317-2347$ - v. 6, n. 3 (2017)

metódica com seus educandos, e com isso, criar métodos para incitar neles a produção do conhecimento (FREIRE, 2015). Isso faltava em Wei naqueles momentos.

Em sequência, dois momentos devem ser destacados: a ida de uma aluna para uma escola de atletas, mesmo contra a vontade de Wei, e um tumulto na sala que acabou com toda a caixa de giz que havia. É nesse contexto que se torna perceptível a mudança crescente no comportamento da jovem, passando a se enxergar como uma professora, como adulta responsável pela definição daquelas crianças. É criada uma relação de professor-aluno, especialmente quando o menino Huike é levado para a cidade grande a fim de trabalhar, devido às dívidas que sua família possuía. Quando isso ocorre, há uma quebra em toda a linearidade do filme, porque comportamentos estão prestes a mudar.

Retomando os conceitos expostos por Freire (2015), temos agora um ensino com respeito aos saberes dos educandos, bem como a exigência da pesquisa na prática educativa. A professora Wei, a partir deste momento, não mais se prende aquilo que lhe fora requisitado (exercícios repetitivos para memorização). Agora, ela faz uso da necessidade de conseguir dinheiro para ir à cidade encontrar e trazer de volta o pequeno Huike, e garantir seu salário. Para conseguir os recursos que necessita, passa a ensinar matemática aos alunos a partir de situações práticas. É a partir disso que a escola passa a fazer sentido para os alunos.

Não obtendo sucesso e sem conseguir completar a viagem até a capital, como penetra num ônibus, a professora Wei caminha a pé durante muitas horas, até conseguir uma carona que a levasse ao seu destino. Enfrenta frio, fome, cansaço, tudo em busca do seu aluno, até ficar um dia e meio na entrada de uma estação de TV, em busca do administrador. Ao ficar sabendo disso, o administrador vai ao encontro da professora e a encaminha para o programa de maior audiência da rede. No momento em que Wei faz um comovente chamado ao seu aluno e traz para o lado rico e próspero da China a situação de muitas escolas interioranas, a professora consegue encontrar Huike, que estivera mendigando para poder se alimentar. Diante disso, há uma enorme repercussão em todo o país, e os olhos da China rica se voltam para a pequena aldeia de Shuiquan, onde agora, haveria a construção de uma nova escola, com recursos doados para a melhoria da educação naquela região.

Positivamente, e contribuindo para a reflexão mencionada neste trabalho, o filme chinês traz à tona uma realidade vivida em diversas partes do mundo, até mesmo em países considerados ricos. Fica evidente, nessa perspectiva, o descaso quanto aos investimentos em educação de qualidade para todos os estratos sociais. Com isso os agentes educacionais 


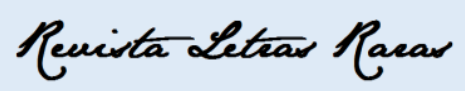

ISSN: $2317-2347$ - v. 6, n. 3 (2017)

precisam se esforçar em dobro para a construção de conhecimento nos alunos. E, assim como ocorreu na aldeia de Shuiquan, em muitos lugares, entre eles o Brasil, infelizmente, muitas vezes não há Formação Docente adequada, o que leva o professor a aprender na prática.

Nenhum a menos produz um enorme envolvimento com o público que o assiste, especialmente com aqueles que estão inseridos no contexto educativo. A situação da professora Wei se associa diretamente com a de muitos professores, porque mostra de forma reflexiva o que foi apresentado por Paulo Freire: "Quem ensina aprende ao ensinar e quem aprende ensina ao aprender." (FREIRE, 2015, p. 25). A professora Wei formou-se enquanto formava, e os alunos a formavam enquanto eram formados. O filme é indicado para todo o público que atua na área da educação e busca uma reflexão sobre a prática de ensino.

Recebimento: 13/10/2017

Aceite: $26 / 12 / 2017$ 